\title{
Transversal and Professional Skills Self-Efficacy Scale: Cultural Adaptation and Evidence of Validity
}

\section{Alyane Audibert ${ }^{1}$ (D) Diana Aguiar Vieira ${ }^{2}$ (D) Alexsandro Luiz De Andrade $^{3}$ (D) Manoela Ziebell de Oliveira ${ }^{4}$ (D)}

Published online: 8 July 2020

(C) Associação Brasileira de Psicologia 2020

\begin{abstract}
Today, the preparation for working life and lifelong career management is becoming increasingly demanding challenges. Hence, in recent years, transversal competences have become more important. The aim of this paper is to present the adaptation study to the Brazilian context of the Transversal and Professional Skills Self-Efficacy Scale (TPS-SE), originally developed in Portugal. The sample consists of 658 Brazilians, $85.7 \%$ women. Exploratory and confirmatory factor analysis procedures were performed, and the final model presented satisfactory adjustment ratios, offering an alternative version with a general factor, and confirming the three-factor structure of the original scale, which assesses confidence in the ability to perform (1) personal and interpersonal skills in the workplace, (2) complex personal skills, and (3) transversal technical skills. It can be concluded that TPS-SE_Br can be used in intervention and research contexts, either in the form of general indicators, clustered in dimensions or in an individual item analysis.
\end{abstract}

Keywords Statistical validity $\cdot$ Self-efficacy $\cdot$ Competence $\cdot$ Professional development

In the twenty-first century work context, both the preparation for working life in the initial stages of one's career and lifelong individual career management are increasingly demanding challenges (Duarte et al. 2010). In that context, factors like globalization and rapid technological growth and evolution have influenced the type of professional

Alyane Audibert

alyaneaudibert@yahoo.com.br

1 Pontifical Catholic University of Rio Grande do Sul, ESPM-Sul, Porto Alegre Rio Grande do Sul Brazil

2 ISCAP, CEOS.PP, Polytechnic Institute of Porto, Porto Portugal

3 Federal University of Espírito Santo, Vitória Brazil

4 Pontifical Catholic University of Rio Grande do Sul, Porto Alegre Brazil 
competences that is required (Kotter 1996; Shultz and Olson 2013). Hence, in recent years, transversal competences have gained importance in selection processes and in maintaining one's job.

Transversal competences are the ones that favor good performance in the world of work, as they help subjects to better cope with different types of work situations (Moreno 2005). They can also be defined as those "which are common to several professions and (...) which can be acquired in the exercise of one profession and which will allow for a possible transfer to other categories" (Rey 2002, p. 53). It should be noted that they can be social, relational, technical, learning or career-related (Klink, Boom \& Schlusmans, 2007), whenever they can be transferred to different occupational activities.

Several authors argue that transversal skills are important for insertion and stability in the labor market, as they provide individuals with the necessary tools to cope with the constant changes in the working world (Drummond et al. 1998; Klink et al. 2007; Palací and Moriano 2003; Rey 2002; Smith et al. 1989; Talavera and Pérez-González 2007). These transversal, transferable, and adaptable competences play a complementary role to the specific technical competences (Shakir 2009).

In a study that aimed to analyze the key competences of higher education graduates, 41 categories of transversal competences were identified (Cabral-Cardoso, Estevão, \& Silva, 2006). Among them, some were broader, such as "group work," and others were more specific to certain areas of activity, such as "risk-taking." The competences of which the young graduates showed the greatest mastery were the following: interpersonal relationship, information and communication technologies, availability for continuous learning, group work, adaptation to change, ability to listen, and problemsolving. In contrast, young professionals showed less mastery of leadership, influence/ persuasion, foreign languages, motivation of others, risk-taking, negotiation, and business sensitivity.

Despite the acknowledged importance of the development of transversal skills for vocational training, there is little convergence as to which of them are the most important (Lucas et al. 2004; Moreno 2005, 2006; Silva and Teixeira 2012). The most valued transversal skills are those related to communication, teamwork, interpersonal relationships, problem-solving, creativity and innovation, adaptability, responsibility, availability and flexibility, proactivity, and initiative; motivation, resilience, and willingness to learn (Cabral-Cardoso et al. 2006; Gata et al. 2014; González and Wagenaar 2006; Robles 2012; Shuayto 2013; Silva 2008); autonomy, communication, reflection, critical spirit, concern, and concern for others (Costa 2011); the ability to adapt to a rapidly changing environment and continuous learning (Dias 2006); teamwork, interpersonal relationships, responsibility, individual or group decision-making, and ability to share knowledge (Rua 2011); and problem-solving, organization at work, responsibility at work, teamwork, autonomy, interpersonal relationship, creativity, and flexibility (Moreno 2006).

That does not mean that specific technical skills have lost their importance. They are still a necessary condition for working, but they no longer seem enough for professionals to stay in the current labor market (The Future of Education, according to experts at Davos 2018).

In times of uncertainty, complexity, and instability (Baruch and Yochanan 2016), self-efficacy is one of the essential tools in vocational development and career 
management (Creed et al. 2009; Duffy 2010; Kuijpers and Scheerens 2006; Savickas 2009; Van der Heijde 2014). As a central part of cognitive social theory, it is understood as “(...) people's beliefs in their ability to organize and perform actions to achieve certain results" (Bandura 1997, p. 3). These beliefs are developed through four information sources: personal experience, vicarious experience, verbal persuasion, and physiological and affective states (Bandura 1997).

Personal experience refers to the interpretations of previous experiences and is the greatest source of influence on the formation of self-efficacy beliefs (Bandura 1997). Vicarious experiences develop by observing other people performing a particular activity (Pajares 2002). Verbal persuasion is made up of verbal judgments received by an individual in the form of positive or negative feedback to the performance they can produce in a given activity (Bandura 1997; Pajares 2002). Physiological and affective states refer to physical and emotional reactions derived from activities that require strength and endurance (Bandura 1997; Pajares 2002).

It is noteworthy that self-efficacy beliefs should be analyzed considering the context in which they are presented. That is, they exist and operate in different domains. Some of them are explained below.

Self-efficacy in the field of career choice refers to individuals' confidence to engage in professional decision-making (Ambiel and Hernández 2016; Luzzo 1996). Perceived social self-efficacy is understood as the individuals' confidence in their ability to engage in social interaction tasks necessary to initiate and maintain interpersonal relationships (Riaz Ahmad et al. 2014). In turn, entrepreneurial self-efficacy is defined as the belief in the ability to perform tasks and roles for entrepreneurial outcomes (Chen et al. 1998), and plays an important role in pursuing entrepreneurial careers and engaging in entrepreneurial behaviors in other activities (Newman et al. 2019).

Self-efficacy in the Transition to Work refers to the individuals' trust in their ability to perform tasks related to job seeking and the start of one's professional activity. It also refers to the level of confidence to cope with the challenges that come up in the transition process to the world of work, in terms of job seeking as well as adaptation to work (Vieira and Theotonio 2018). Finally, Transversal and Professional Skills Self-Efficacy refers to the level of confidence in one's current ability to demonstrate each skill (Vieira 2014).

In a study entitled "Prepared to work" (Vieira and Marques 2014), the research question was: What are the skills that grant higher education graduates' employability? For that purpose, and considering that transversal skills have been increasingly valued in the labor market (Andrews and Higson 2008; Archer and Davidson 2008; Cotton 2001; Harvey and Bowers-Brown 2004; Hawkins and Winter 1995; Hernández-March et al. 2009), the authors conducted an extensive review of the literature, searching for the transversal and professional skills required for the labor market. In this study, we considered personal and interpersonal skills (soft skills), as well as technical skills that are common to various professional activities and, as such, allow the transferability of one professional profile to another. After this systematization, qualitative and quantitative studies were conducted involving students, recent graduates, and employers.

In one of these studies, the Transversal and Professional Skills Self-Efficacy Scale (TPS-SE; Vieira and Marques 2014) was used to analyze each competence, that is, at the level of the disaggregated items. Despite the theoretical absence of an a priori underlying dimensional structure of the TPS-SE, an exploratory factor analysis was performed using principal component analysis as the extraction method (Vieira 2014), in a sample 
of 1027 recent higher education graduates from Portugal (76\% female; mean age of 27 \pm 5 years). Based on an eigenvalue greater than one and scree plot observation, the initial solution pointed to the existence of three factors, and all items showed factor loadings greater than $0.40\left(\mathrm{KMO}=0.96\right.$; Bartlett, $\left.\chi^{2}(210)=12,354.2 ; p<0.001\right)$. Using the varimax rotation method, the final solution revealed a three-dimensional structure, with all the initial 21 items, factor loadings between 0.45 and 0.74 , and $60 \%$ of the total explained $(a=0.94)$. Factor 1 explained $23 \%$ of the total variance and was composed of ten items that assess self-efficacy in view of the capacity to evidence personal and interpersonal skills in the workplace, such as adaptation, flexibility, and teamwork $(a=$ 0.91). Factor 2 explained $22 \%$ of the total variance and consisted of seven items, which assess confidence in relation to complex personal competences, such as problem analysis and solving or creativity and innovation $(a=0.88)$. Factor 3 explained $15 \%$ of the total variance and was composed of four items related to confidence in the ability to perform transversal technical skills, such as mastery of foreign languages and the use of information and communication technologies $(a=0.75)$.

Based on the above, the objective of this paper is to present the adaptation study to the Brazilian cultural context and evidence of the psychometric properties of the TPSSE (Vieira 2014). The instrument was originally developed in Portugal.

\section{Method}

\section{Participants}

The participants were 407 college students of psychology courses and 251 professional psychologists, totaling 658 Brazilians, being $85.7 \%$ women. The average age was 28 years $(\mathrm{SD}=8.32)$. Of the total participants, $47.4 \%$ had a paid job at the time of data collection. Most participants were from the South of Brazil (47.6\% students and $51.9 \%$ professionals), but there were also representatives from other regions: Southeast (26.6\% students and $35.4 \%$ professionals), Northeast $(12.8 \%$ students and $6.7 \%$ professionals); Midwest (9.8\% students and 5.3\% professionals), and North $(3.1 \%$ students and $0.6 \%$ professionals).

Most $(63 \%)$ of the students were enrolled in private universities. Among them, $18.4 \%$ were enrolled in the first years of the psychology course (1st to 3rd semester), $37.1 \%$ were in the middle of the course (4th to 7 th semester), and $44.4 \%$ were in the final stage (from 8 th to 10th semester). Considering the professionals, $11.3 \%$ had obtained their degree in the past year, 35.8\% had graduated between 1 and 4 years before data collection, and $52.9 \%$ had graduated 5 to 10 years before. Regarding family income, $55.7 \%$ of the students and $27.4 \%$ of the professionals reported gaining up to $\mathrm{R} \$ 4000.00$, while $21.3 \%$ of the students and $42.1 \%$ of the professionals reported income of over R $\$ 7000.00$.

Although the original version of the Transversal and Professional Skills Self-Efficacy Scale was first tested on a sample of students from different areas of knowledge, in this study, we chose to test it in a sample composed of both students and professionals. In view of the possible differences due to the stage of the career development of participants, the authors decided to compose a sample exclusively of psychologists to permit a deeper discussion of the results, considering the peculiarities of this professional group. 


\section{Instrument}

The TPS-SE (Vieira 2014) is a self-report instrument that aims to assess the confidence level against a set of 21 transversal and professional competences. Each item represents a transversal and professional competence and, next to each item, the definition of each competence is presented based on examples of activities and/or attitudes representative of each competence, such as creativity and innovation, creating new solutions or ideas at work; demonstrating originality and creativity; suggesting innovative proposals, and motivation for excellence, maintaining a positive attitude and being persistent in the face of difficulties; being proactive in the pursuit of continuous improvement; and being attentive to detail without losing sight of the ultimate goal. This is an aspect that adds value to this instrument as the presentation of these definitions aims to prevent respondents from giving a different meaning to the competences to be assessed. Answers are to be given on a five-point Likert scale, ranging from " $1=$ not confident at all" to "5 = totally confident."

\section{Data Collection Procedure}

Initially, a cognitive interview was conducted on the fitness and comprehension of the language in the "TPS-SE" (Vieira 2014) by the target audience, considering the competences and their definitions. This stage consisted of requesting the completion of the scale, as it was constructed (in Portuguese of Portugal), to five potential participants, being three undergraduate students in psychology (one at the beginning, one in the middle, and one at the end of the course) and two psychology professionals (one recent graduate and another graduated for 4 years). Afterwards, the participants were asked item by item, regarding the competences as well as their definitions, to check their language comprehension and thoughts when they were completing the scale.

Although the wording of most items is identical in Portuguese from Brazil and from Portugal, during these interviews, we identified the need for language adaptation from Portuguese of Portugal (PT-PT) to Brazilian Portuguese (PT-BR) in some of the items. Examples include changing the terms "equipa" (PT-PT) to "equipe" (PT-BR) and "planeamento" (PT-PT) to "planejamento" (PT-BR). Thus, in the second stage of the semantic validation, two researchers separately made the identified adjustments, which were later condensed by a third, and then submitted to the author of the original scale. After this validation, data were collected online through the Qualtrics platform.

The participants were contacted through e-mail messages from psychology colleges and psychologist associations, as well as social media messages and messaging tools. The "snowball" technique was used, in which participants are asked to forward the message about the data collection to their contacts and/or pass on the contact information of potential participants to the researchers.

\section{Data Analysis Procedures}

Since this was the first study to adapt and use the TPS-SE in the Brazilian context, the authors decided to initially explore the construct evidence using an exploratory factor analysis (EFA), followed by the test of confirmatory models considering the Brazilian and the Portuguese structures (CFA). To perform these procedures, the database was 
divided into two groups, randomly distributed and equalized by gender $(\mathrm{EFA}=329$; CFA = 329). To evaluate the dimensional structure of the TPS-SE, the parallel analysis technique (Timmerman and Lorenzo-Seva 2011) was used. Then, due to the ordinal nature of the data, the factorial structure of the scale was explored using EFA. The estimator model for this analysis was the unweighted least squares (ULS), based on a polychoric correlations matrix (Lorenzo-Seva and Ferrando 2013).

To provide additional evidence of construct validity and permit the identification of the best TPS-SE structure for the Brazilian context, confirmatory factor analysis (CFA) was performed. The analysis used the estimator weighted least square mean and variance adjusted (WLSMV) and was performed with Mplus (Muthén and Muthén 2012). Omega coefficients were tested in both analyses to identify the internal consistency of the scale dimensions.

\section{Results}

\section{Descriptive and Exploratory Factor Analysis}

The results of the Kaiser-Meyer-Olkin (KMO) index and Bartlett's sphericity test were significant $\left(\mathrm{KMO}=0.91\right.$; Bartlett, $\left.\chi^{2}(210)=3041.3 ; p<0.001\right)$. In the next step, the TPS-SE items were submitted to EFA through parallel analysis based on a polychoric correlation matrix to identify the number of dimensions. The analysis suggested one dimension, indicating a divergence from the original model, based on the Portuguese version of the scale. Table 1 indicates the variance established by empiric and random values generated by parallel analysis. As shown in Table 1, after the second component, the eigenvalue was greater than the empirical value. This result indicates the retention of only the first factor for the structural solution.

Table 2 shows descriptive statistics of the 21 items of TPS-SE_Br and results from an exploratory factor analysis performed to extract one dimension, as suggested by the parallel analyses. The model was extracted with an ULS estimator and a promin rotation.

The results showed item-level appropriate variability as all item values range from 1 to 5 , except for item 18 , which has a minimum value of 2 . The item averages range from 2.31 to 4.35 , and the standard deviation values are distributed between 0.78 and 1.30 , being mostly superior to the unit, which indicates appropriate variability in the answers, considering that the answer options vary between 1 and 5 . The asymmetry (between -0.94 and 0.62 ) and kurtosis (between -1.0 and 0.0 ) coefficients of each item are within appropriate limits. The EFA indicated that the one-factor model

Table 1 Empiric and random eigenvalues of the first eight components generated by parallel analysis

\begin{tabular}{|c|c|c|c|c|c|c|c|c|}
\hline \multirow[t]{2}{*}{ Variance } & \multicolumn{8}{|c|}{ Components } \\
\hline & 1 & 2 & 3 & 4 & 5 & 6 & 7 & 8 \\
\hline Empiric & 45.36 & 7.15 & 6.96 & 6.01 & 4.52 & 4.25 & 3.88 & 3.14 \\
\hline Random & 9.76 & 8.96 & 8.40 & 7.87 & 7.40 & 6.95 & 6.50 & 6.05 \\
\hline
\end{tabular}


Table 2 Factor loading, asymmetry and kurtosis of the TPS-SE_Br

\begin{tabular}{lcclll}
\hline Item No. & Asymmetry & Kurtosis & $M$ & SD & Factor loading \\
\hline 1 & 0.01 & -0.53 & 3.32 & 0.99 & 0.70 \\
2 & -0.14 & -0.67 & 3.43 & 1.00 & 0.68 \\
3 & -0.14 & -0.75 & 3.30 & 1.11 & 0.59 \\
4 & 0.12 & -0.83 & 2.99 & 1.17 & 0.45 \\
5 & 0.09 & -0.52 & 2.99 & 1.02 & 0.61 \\
6 & -0.09 & -1.00 & 3.22 & 1.23 & 0.60 \\
7 & -0.54 & -0.37 & 3.95 & 0.93 & 0.64 \\
8 & -0.28 & -0.75 & 3.67 & 1.02 & 0.59 \\
9 & -0.23 & -0.57 & 3.53 & 1.01 & 0.66 \\
10 & -0.07 & -0.83 & 3.19 & 1.14 & 0.60 \\
11 & -0.03 & -0.87 & 3.19 & 1.15 & 0.61 \\
12 & -0.13 & -0.83 & 3.37 & 1.10 & 0.66 \\
13 & -0.66 & -0.08 & 4.05 & 0.88 & 0.75 \\
14 & -0.23 & -0.60 & 3.65 & 0.97 & 0.73 \\
15 & -0.26 & -0.50 & 3.61 & 1.00 & 0.57 \\
16 & -0.28 & -0.69 & 3.52 & 1.08 & 0.72 \\
17 & -0.74 & -0.22 & 3.99 & 1.02 & 0.52 \\
18 & -0.94 & 0.00 & 4.35 & 0.78 & 0.60 \\
19 & -0.25 & -0.89 & 3.63 & 1.08 & 0.48 \\
20 & 0.69 & -0.68 & 2.31 & 1.30 & 0.36 \\
21 & -0.09 & -0.65 & 3.43 & 1.02 & 0.69 \\
\hline & & & & &
\end{tabular}

explained $41 \%$ of the variance of data, and the result of the reliability test (Cronbach alpha) was very good $(\alpha=0.90)$, as well as the McDonald's indicator $(\omega=0.91)$.

\section{Confirmatory Factor Analysis}

Considering that the model adapted to the Brazilian context presented a factorial structure that diverged from the original version (Portugal), two models were tested to evaluate the best fit of the dimensional structure of the measure in the Brazilian context. The CFA procedure considered two models for evaluation: M1, derived from the EFA with Brazilian sample; and M2, which had a three-dimensional structure, derived from the original Portuguese version of the measure. The parameters were estimated using the WLS estimator. Table 3 presents the adjustment indices of the models.

As shown in Table 3, both models presented good fit indicators. Model 2 showed more satisfactory adjustment indices $\left(\chi^{2}\right.$, CFI, TLI, RMSEA, and SRMR) and greater adherence to the theoretical bases that underlie the development of the scale though. The reliability tests provided support for the three-factor version, represented by the self-efficacy regarding: (1) personal and interpersonal skills in the workplace $(\alpha=0.85$ and $\omega=0.86)$, (2) complex personal skills ( $\alpha=0.82$ and $\omega=0.83)$, and (3) transversal technical skills $(\alpha=0.65$ and $\omega=0.70)$. 
Table 3 Confirmatory factor analysis of TPS-SE_Br

\begin{tabular}{lllllll}
\hline Model & $\chi^{2}$ & DF & CFI & TLI & RMSEA (90\% CI) & SRMR \\
\hline Model 1 (M1) & 412 & 189 & 0.973 & 0.969 & $0.060(0.052-0.068)$ & 0.065 \\
Model 2 (M2) & 348 & 186 & 0.980 & 0.977 & $0.052(0.043-0.060)$ & 0.060 \\
\hline
\end{tabular}

Note. $\chi^{2}$, Chi-square; $D F$, degrees of freedom; $C F I$, comparative fit index; TLI, Tucker-Lewis index; RMSEA $(90 \% \mathrm{CI})$, root mean square error of approximation and respective confidence interval; SRMR, standard root mean squared residual

\section{Discussion}

The study showed positive psychometric indicators for the Brazilian Portuguese version of the Transversal and Professional Skills Self-Efficacy Scale (TPS-SE_Br). The methodological steps taken in this study assured the quality of the items adapted to Brazilian Portuguese, as well as psychometric properties that advocate for the use of the measure in the context of research and the diagnosis of self-efficacy regarding transversal and professional skills at work. Moreover, the results show the potential for the use of the tool in evaluation processes, as it can present an overall self-efficacy score, as well as the result of each of the three dimensions identified in the Portuguese version of the instrument proposed by Vieira (2014).

The concern with identifying the key or transferable competences the job market requires from the perspective of graduates and employers has been constant in the literature (Cabral-Cardoso et al. 2006; Lechasseur et al. 2018; Martins 2015; Mendonça et al. 2015; Parra 2014; Vieira and Marques 2014). Nevertheless, there does not yet appear to be a consensus on the transversal and professional skills set necessary to ensure employability or career success today or in the future (Lucas et al. 2004; Moreno 2005, 2006; Silva and Teixeira 2012). Even so, the McKinsey \& Company report "Education to employment: Getting Europe's youth into work - A road with many barriers" (Mourshed et al. 2014) pointed out that young people are not being prepared with the skills they need in the world of work. Initiatives such as the Core Skills for 21st Century Professionals Project - CoSki21 (Vieira et al. 2018), which aims to define and evaluate a framework for key competences, seem to contribute in this direction though.

In addition to identifying a set of relevant skills for work, it is also pertinent to assess the extent to which the individual feels confident to put them in practice, from the perspective of higher education institutions and organizations as well as at the personal level. And this is precisely the contribution of the "TPS-SE" (Vieira 2014), originally developed in Portugal and, in this study, adapted and validated to the Brazilian context.

The adequacy of the indices found in the test of the models (one and three dimensions) reveals that the instrument could be used for a general score or with the original structure and can be used in this format for use in transcultural research and also in interventions in the Brazilian context, safeguarding the limits regarding the population in which the scale was applied. Specifically, in the area of career counseling, TPS-SE can be used as a pre- and post-test measure for process evaluation, especially in cases where there is a need to develop or improve transversal and professional skills, such as the case of Counseling Centers in Higher Education Institutions, with university students. 
Even with a wide area of expertise, it is considered common to the profession of psychologists to work with people, individually or in groups, and diagnostic and intervention activities (Conselho Federal de Psicologia 2000; Lima and Cerveny 2012; Moraes et al. 2002; Sobiraj et al. 2016). In this sense, it is expected that these professionals, over time, develop their skills and abilities for the development of their work with technical mastery, but also transversal, which can be applied to other professions. The study by Bedin et al. (2013) corroborates this expectation by pointing out the unpreparedness felt by psychologists at the end of undergraduate studies, also observing that, over time, the development of skills and professional experience help to form professional identity, which leads to professional fulfillment. Although it was not the focus of this study to assess levels of confidence in the performance of skills among students and professionals, it is considered that TPS-SE_Br can help to monitor the development of these skills throughout the training of psychologists, but also other professions, results that may be interesting both individually, with a view to self-knowledge and personal development, as well as institutionally, in order to evaluate and improve the curriculum and related pedagogical activities. So, the use of the TPS-SE_Br is considered appropriate in populations with higher education schooling, as for now the scale has only been applied to this population. Future studies with other types of samples are suggested though, considering a greater diversity of professional areas and different levels of education.

In addition, after the adaptation and validation procedures of the TPS-SE_Br, it will also be possible, for example, to replicate the study "Ready to work?" (Vieira and Marques 2014), which revealed the skills most valued by employers, in descending order of preference: (1) problem analysis and resolution, (2) creativity and innovation, (3) adaptation and flexibility, (4) planning and organization, (5) motivation for excellence. The same study also identified that Higher Education Institutions (HEIs) have been less able to prepare their students for the following competences: leadership, risk consideration, decision-making and accountability, and fluency in foreign languages. This diagnosis, whether the same or different from that found in Portugal, can be highly valuable especially to HEIs, as they may provide clues about the competences that are being developed and those that still require adjustment.

In a previous study (Cabral-Cardoso et al. 2006), it was found that the highest levels of mastery were for the following: interpersonal relationships, information and communication technologies, readiness for continuous learning, group work, adaptation to change, listening skills, and problem-solving. In contrast, young professionals showed less mastery of leadership, influence/ persuasion, foreign languages, motivation of others, risk consideration, negotiation, and business sensitivity.

Both studies (Cabral-Cardoso et al. 2006; Vieira and Marques 2014) provide clues about transferable skills that are being developed satisfactorily, such as problem analysis and resolution, and adaptation and flexibility, as well as those that need more emphasis, namely leadership, risk consideration, and foreign language fluency. Based on the present study, it can be argued that the TPS-SE_Br is a valid instrument that can help to clarify the confidence levels for the performance of 21 transversal skills in the Brazilian context. 


\section{Final Considerations}

The aim of this research was to present the study of the psychometric properties of the adaptation to the Brazilian context of the TPS-SE (Vieira 2014), originally developed in Portugal. The dimensionality found in the original version of the scale was replicated in the confirmatory factor analysis, with appropriate and satisfactory results. The study also brings a new perspective on the general evaluation of the self-efficacy regarding transversal and professional skills though, based on the results obtained in the exploratory factor analysis. These results shed light on the theoretical discussion about the subject, as well as about the peculiarity of cross-cultural adaptation of instruments, contributing to the literature by presenting an agenda for future studies on the dimensionality aspects of the construct (invariance tests for gender and socioeconomic aspects).

This study effectively confirmed the three-dimensional structure of the TPS-SE_Br, in which the first factor assesses the subjects' confidence - or self-efficacy beliefs - in their ability to evidence personal and interpersonal work skills. A second factor is related to self-efficacy beliefs in the face of more complex personal work skills, and a third factor reflects the confidence in the ability to perform transversal technical skills, as well as in the specific area of graduation.

Aggregating the results into dimensions, as opposed to the individual item scores, is a parsimonious option that may facilitate the analysis of transversal and professional self-efficacy relationship with other variables in a research context. In interventionfocused contexts, however, the detail provided by each of the items may be more advantageous. If we consider the sources of self-efficacy-direct experiences of success, observational learning, verbal persuasion, and emotional and physiological states - the career intervention possibilities from the item scores could be of great use.

Although the psychometric indicators of the scale were satisfactory, both in its TPSSE and TPS-SE_Br versions, this study comes with limitations. Among them, we can mention the small variability of the sample, as it contained only psychologists and psychology students, and the lack of effective performance data of the participants in their work or academic activities, relying only on self-reported information.

The validation process of any instrument is never finished, so future psychometric studies should be performed on independent and more diverse samples in terms of area and level of training, both in Brazil and Portugal. Additionally, concurrent and divergent validity studies that crossed the transversal and professional skills self-efficacy assessed through the TPS-SE with other psychological constructs would be pertinent.

This scale may permit the expansion of the application of the cognitive social theory in the career area to the transversal and professional competences. In this sense, studies relating TPS-SE with other concepts of the cognitive social theory, such as self-efficacy sources, expected outcomes, and/or professional goals, could make an important contribution not only in terms of theory development but also to the intervention. Another route of theoretical development in this same conceptual perspective could explore whether the consequences of self-efficacy beliefs are also applied in this area. Does greater transversal and professional skills self-efficacy also mean better performance in the work context? Research that answers this question will surely offer relevant contributions in this area.

The availability of an original tool with appropriate psychometric characteristics to assess transversal competences will hopefully be able to encourage future research. 
Finally, its use can contribute to the development of soft skills-focused interventions that are increasingly necessary and valued in the job world.

Funding Information This study was funded by Coordination for the Improvement of Higher Education Personnel.

Data Availability The datasets used and/or analyzed during the current study are available from the corresponding author on reasonable request.

\section{References}

Ambiel, R.A.M., \& Hernández, D.N. (2016). Relações entre Autoeficácia para Escolha Profissional, Exploração e Indecisão Vocacional. Revista Brasileira de Orientação Profissional, 17(1), 67-75. Retirado de http://pepsic.bvsalud.org/scielo.php?script=sci_arttext\&pid=S1679-33902016000100008 $\& \operatorname{lng}=$ pt\&tlng $=$ pt.

Andrews, J., \& Higson, H. (2008). Graduate employability, 'soft skills' versus 'hard' business knowledge: A European study. Higher Education in Europe, 33, 411-422. https://doi.org/10.1080 /03797720802522627.

Archer, W., \& Davidson, J. (2008). Graduate employability: What do employers think and want? London: The Council for Industry and Higher Education.

Bandura, A. (1997). Self-efficacy: The exercise of control. New York: Freeman.

Baruch, Y., \& Yochanan, A. (2016). The ecosystem of labor markets and careers. People \& Strategy, 2016, p. 16+. Academic OneFile. Retirado de http://go.galegroup.com/ps/anonymous?id=GALE\% 7 CA458159878\&sid=googleScholar\&v=2.1\&it=r\&linkaccess=abs\&issn=19464606\&p=AONE\&sw=w.

Bedin, L. M., Sarriera, J. C., \& Paradiso, Â. C. (2013). Desenvolvimento de carreira em psicólogos: tarefas evolutivas de estabelecimento. Revista Brasileira de Orientação Profissional, 14(1), 87-98. Retirado de http://pepsic.bvsalud.org/scielo.php?script=sci_arttext\&pid=S1679-33902013000100009\&lng=pt\&tlng=pt.

Cabral-Cardoso, C., Estévão, C. V., \& Silva, P. (2006). Competências transversais dos diplomados do Ensino Superior: perspectiva dos empregadores e diplomados. Guimarães: TecMinho.

Chen, C., Greene, P., \& Crick, A. (1998). Does entrepreneurial self-efficacy distinguish entrepreneurs from managers? Journal of Business Venturing, 13, 295-316. https://doi.org/10.1016/S0883-9026(97)00029-3.

Conselho Federal de Psicologia (2000). Pesquisa feita junto aos Associados do Conselho Federal de Psicologia: Relatório Final. Brasília: DF. Recuperado em 12 de agosto de 2012, de http://www.pol.org. br/publicacoes/pdf/Pesquisa_WHO.pdf.

Costa, M. L. (2011). Mais Saber, Melhor Enfermagem: A repercussão da formação na qualidade de cuidados (Tese de doutoramento). Retirado de http://recil.grupolusofona.pt/bitstream/handle/10437/1576/Tese $\% 20$ Doutoramento\%20-\%20Mais\%20Saber\%2c\%20Melhor\%20Enfermagem.pdf?sequence=1

Cotton, K. (2001). Developing employability skills, Northwest Regional Educational Research Laboratory, Portland, OR. Retirado de www.nwrel.org/scpd/sirs/8/c015.html

Creed, P. A., Fallon, T., \& Hood, M. (2009). The relationship between career adaptability, person and situation variables, and career concerns in young adults. Journal of Vocational Behavior, 74, 219-229. https://doi.org/10.1016/j.jvb.2008.12.004.

Dias, M. F. (2006). Construção e Validação de um Inventário de Competências. Contributos para a Definição de um Perfil de Competências do Enfermeiro com o Grau de Licenciado. Lisboa: Lusociência.

Drummond, I., Nixon, I., \& Wiltshire, J. (1998). Personal transferable skills in higher education: The problems of implementing good practice. Quality Assurance in Education, 6(1), 19-27. https://doi.org/10.1108 /09684889810200359.

Duarte, M. E., Lassance, M. C., Savickas, M.L., Nota, L., Rossier, J., Dauwalder, J.-P., Guichard, J., Soresi, S., Van Esbroeck, R., Vianen, A. E. M. van (2010). A Construção da Vida: Um Novo Paradigma para Entender a Carreira no Século XXI. Interamerican Journal of Psychology, 44(2), 392-406. Retirado de http://www.redalyc.org/articulo.oa

Duffy, R. D. (2010). Sense of control and career adaptability among undergraduate students. Journal of Career Assessment, 18(4), 420-430. https://doi.org/10.1177/1069072710374587. 
Gata, H., Oliveira, A., \& Silva, R. (2014). Faz-te ao Mercado. Estudo sobre o (des)encontro entre a procura e a oferta de competências no mercado de trabalho e a sua relação com a empregabilidade jovem. Lisboa: Associação para o Desenvolvimento.

González, J., \& Wagenaar, R. (2006). Tuning educational structures in Europe. Bilbao: Universidade de Deusto.

Harvey, L. \& Bowers-Brown, T. (2004). Employability cross-country comparisons (Winter 4/05). Graduate Market Trends. Retirado de http://www.prospects.ac.uk/cms/ShowPage/Home_page/Members__Log_ in/Labour_market_information/Graduate_Market_Trends/Employability_cross_country_comparisons Winter_04_05_p!epmjli.

Hawkins, P., \& Winter, J. (1995). Skills for graduates in the 21st century. London: Association of Graduate Recruiters.

Hernández-March, J., Peso, M. M., \& Leguey, S. (2009). Graduates skills and higher education: The employers' perspective. Tertiary Education and Management, 15, 1-16. https://doi.org/10.1080 $/ 13583880802699978$.

Klink, M., Boon, J. \& Schlusmans, K. (2007). Competências e ensino superior profissional: Presente e futuro. Revista Europeia de Formação Profissional, 40(1), 72-89. Retirado de https://www.academia. edu/10121789/Compet\%C3\%AAncias_e_ensino_superior_profissional_presente_e_futuro

Kotter, J. P. (1996). Leading change. Boston, Harvard Business School Press.

Kuijpers, M. A., \& Scheerens, J. (2006). Career competencies for the modern career. Journal of Career Development, 32, 303-319. https://doi.org/10.1177/0894845305283006.

Lechasseur, K., Caux, C., Dollé, S., \& Legault, A. J. (2018). Ethical competence: An integrative review. Nursing Ethics, 25(6), 694-706. https://doi.org/10.1177/0969733016667773.

Lima, M. J., \& Cerveny, C. M. O. (2012). A competência social do Psicólogo: estudo com profissionais que atuam em instituições. Psicologia Ciência e Profissão, 32(2), 284-303. https://doi.org/10.1590/S141498932012000200003.

Lorenzo-Seva, U., \& Ferrando, P. J. (2013). FACTOR 9.2: A comprehensive program for fitting exploratory and semiconfirmatory factor analysis and IRT models. Applied Psychological Measurement, 37(6), 497498. https://doi.org/10.1177/0146621613487794.

Lucas, U., Cox, P., Croudace, C., \& Milford, P. (2004). 'Who writes this stuff?': Student's perceptions of their skills development. Teaching in Higher Education, 9, 55-68.

Luzzo, D. A. (1996). A psychometric evaluation of the career decision-making self-efficacy scale. Journal of Counselling \& Development, 74, 276-279. https://doi.org/10.1002/j.1556-6676.1996.tb01865.x.

Martins, J. P. N. (2015). As Competências de Empregabilidade na Ótica dos Empresários da Beira Interior (Dissertação de Mestrado). Retirado de https://repositorio.ipcb.pt/bitstream/10400.11/3141/1/FINAL.pdf

Mendonça, C., Huet, I., \& Alves, M. (2015). Da Construção à Validação de um Referencial de Competências para uma Licenciatura em Enfermagem. Revista Portuguesa De Pedagogia, 48(2), 109-132. https://doi. org/10.14195/1647-8614_48-2_6.

Moraes, M. C., Madeiro, R. T., \& Barbosa, V. P. (2002). Escolhas, motivos e expectativas de acadêmicos de psicologia quanto a profissão: uma perspectiva psicoeducacional. Dissertação de Mestrado em Psicologia. Programa de Pós-graduação em Psicologia. Universidade Federal do Pará, Belém, PA.

Moreno, M. L. R. (2005). Las demandas sociales y el mundo laboral ante la integración europea de conocimiento universitario. Cuadernos de Integración Europea, 2, 54-68. Retirado de http://cdeuv. es/images/documents/2005-CIE-02.pdf.pdf

Moreno, M. L. R. (2006). Evaluación, balance y formación de competencias laborales transversales: propuestas para mejorar la calidad en la formación profesional y en el mundo del trabajo. Laertes Educación: Barcelona.

Mourshed, M., Patel, J. \& Suder, K. (2014). Education to employment: Getting Europe's youth into work-A road with many barriers. Retirado de http:/www.mckinsey.de/sites/mck_files/files/a4e2e_2014.pdf

Muthén, L. K., \& Muthén, B. O. (2012). Mplus: Statistical analysis with latent variables. User's guide. Los Angeles: Muthén \& Muthén. Retirado de https://www.statmodel.com/download/usersguide/MplusUserGuideVer_7.pdf.

Newman, A., Obschonka, M., Schwarz, S., Cohen, M., \& Nielsen, I. (2019). Entrepreneurial self-efficacy: A systematic review of the literature on its theoretical foundations, measurement, antecedents, and outcomes, and an agenda for future research. Journal of vocational Behavior, 110, Part B, 403-419. doi: https://doi.org/10.1016/j.jvb.2018.05.012.

Pajares, F. (2002). Overview of social cognitive theory and of self-efficacy. Retirado de: http://www.emory. edu/EDUCATION/mfp/eff.html.

Palací, F. J., \& Moriano, J. F. (2003). Inserção do trabalho através do trabalho independente. In J.A. Moriano (Ed.), O novo mercado de trabalho: Estratégias de inserção e desenvolvimento profissional (p. 25-44). Madri: UNED. 
Parra, R. I. C. S. (2014). Competências de empregabilidade - exploração do mercado de trabalho português (Dissertação de Mestrado). Retirado de https://comum.rcaap.pt/bitstream/10400.26/6623/1/Tese\%20 Mestrado.pdf

Rey, B. (2002). As competências transversais em questão. São Paulo: Artmed Editora.

Riaz Ahmad, Z., Yasien, S., \& Ahmad, R. (2014). Relationship between perceived social self-efficacy and depression in adolescents. Iranian journal of psychiatry and behavioral sciences, 8(3), 65-74. Retirado de https://www.ncbi.nlm.nih.gov/pmc/articles/PMC4359727/pdf/ijpbs-8-065.pdf

Robles, M. M. (2012). Executive perceptions of the top 10 soft skills needed in today's work-place. Business Communication Quarterly, 75(4), 453-465. https://doi.org/10.1177/1080569912460400.

Rua, M. (2011). De Aluno a Enfermeiro. Desenvolvimento de Competências em Contexto de Ensino Clínico. Lisboa: Lusociência.

Savickas, M. L. (2009). Pioneers of the vocational guidance movement: A centennial celebration. The Career Development Quarterly, 57, 194-198. https://doi.org/10.1002/j.2161-0045.2009.tb00104.x.

Shakir, R. (2009). Soft skills at the Malaysian institutes of higher learning. Asia Pacific Education Review, 10, 309-315. https://doi.org/10.1007/s12564-009-9038-8.

Shuayto, N. (2013). Management skills desired by business school deans and employers: An empirical investigation. Business Education \& Accreditation, 5(2), 93-105. Retirado de https://ssrn. com/abstract=2239205

Shultz, K. S., \& Olson, D. A. (2013). The changing nature of work and retirement. In M. Wang (Ed.), The Oxford handbook of retirement (pp. 543-558). New York, NY: Oxford University Press.

Silva, P. A. G. (2008). Competências transversais dos Licenciados e sua Integração no Mercado de Trabalho (Tese de mestrado). Retirado de http://repositorium.sdum.uminho.pt/bitstream/1822/9156/1/Relatorio de dissertacao PauloSilva.pdf.

Silva, B. M. B., \& Teixeira, M. A. P. (2012). Autopercepção de competências transversais de trabalho em universitários: construção de um instrumento. Estudos de Psicologia (Natal), 17(2), 199-206. https://doi. org/10.1590/S1413-294X2012000200002.

Smith, D., Wolstencrof, T., \& Southern, J. (1989). Personal transferable skills and the job demands on graduates. Journal of European Industrial Training, 13(8), 25-31. https://doi.org/10.1108 /EUM0000000000207.

Sobiraj, S., Schladitz, S., \& Otto, K. (2016). Defining and explaining career success in psychologists using person and job-based resources. Psychology and Education, 53(2), 1-20.

Talavera, E. \& Pérez-González, J. (2007) Formação em competências socioemocionais através de estágios em empresas. Revista Europeia de Formação Profissional, 40(1), 90-113. Retirado de https://www.cedefop. europa.eu/files/etv/Upload/Information_resources/Bookshop/468/40_pt_repetto.pdf

The Future of Education, according to experts at Davos (2018, 26 de Janeiro). Retirado de https://www. weforum.org/agenda/2018/01/top-quotes-from-davos-on-the-future-of-education/

Timmerman, M. E., \& Lorenzo-Seva, U. (2011). Dimensionality assessment of ordered polytomous items with parallel analysis. Psychological Methods, 16, 209-220. https://doi.org/10.1037/a0023353.

Van der Heijde, C. M. (2014). Employability and self-regulation in contemporary careers. In M. Coetzee (Ed.), Psycho-social career meta-capacities: Dynamics of contemporary career development (pp. 7-17). New York: Springer.

Vieira, D. A. (2014). Do "soft" ao "hard": Questionário de avaliação de Competências para o Trabalho. IX Congresso Ibero-Americano de Psicologia/ $2^{\circ}$ Congresso Nacional da Ordem dos Psicólogos Portugueses. Lisboa: Centro Cultural de Belém, 9-13 de setembro.

Vieira, D.A. \& Marques, A.P. (2014). Preparados para Trabalhar? Lisboa: Consórcio Maior Empregabilidade/ Fórum Estudante.

Vieira, D. A., \& Theotonio, M. (2018). Autoeficácia e sucesso na transição para o trabalho: um estudo longitudinal. Revista Brasileira de Orientação Profissional, 19(1), 31-39 1026707/1984-7270/2019v19 n1p31.

Vieira, D. A., Afonso, A., Bastos, S., Carvalho, P. , \& Poza-Lujan, J. (2018). Competências-chave dos profissionais no Século XXI. Comunicação apresentada no V Congresso Brasileiro Psicologia: Ciência e Profissão, São Paulo. 